\title{
THE ROLES OF ISLAMIC SOCIAL FINANCE IN THE ERA OF POST-COVID-19: POSSIBLE PROSPECTS OF WAQF INSTITUTIONS FOR ECONOMIC REVIVAL
}

\author{
A.W. Ainol-Basirah ${ }^{1},{ }^{2}$ and A.K. Siti-Nabiha ${ }^{1, *}$ \\ ${ }^{1}$ Graduate School of Business, Universiti Sains Malaysia, Penang, Malaysia \\ 2 Faculty of Economics and Management, Universiti Kebangsaan Malaysia, Bangi, Malaysia
}

ABSTRACT - This paper sought to provide an overview of current waqf projects and revenue generation activities by waqf institutions in Malaysia and to further analyse the roles that waqf institutions can play, along with their potential prospects, in helping to stabilise the economic struggle faced during the post-Covid-19 period, especially among vulnerable groups of people and society at large. The findings showed that there is currently positive progress and growth in waqf projects, although some realignment is needed to meet the needs of society in the post-pandemic period. The current waqf model, in particular the cash waqf initiative, needs to be improved to allow for the implementation of a comprehensive economic survival plan through waqf instruments.

\author{
ARTICLE HISTORY \\ Received: $15-6-2020$ \\ Accepted: 1-9-2020

\section{KEYWORDS} \\ Islamic Social Finance, \\ Waqf, \\ Waqf Institution, \\ Covid-19
}

\section{INTRODUCTION}

The world is witnessing and experiencing the unparalleled effects of the global pandemic of Covid-19, which is seriously transforming the social and economic environments of many countries, and having devastating implications for families, culture, and even business enterprises. Predictable disruptive socio-economic challenges such as unemployment and poverty are likely to be tackled in the coming years, and as a result, a strong and sustainable economic system needs to be implemented to cushion the serious impact of the post-Covid-19 socio-economic challenge. While most governments have adopted a range of stimulus packages to alleviate business and individual financial hardship, social and economic turmoil due to the global economic crisis is inevitable in the coming years. Reliance on current economic models, therefore, without significant alterations, could impede government efforts to maintain a healthy socio-economic situation. Hence, the Islamic social finance instruments (including zakah, waqf, sadaqah, qard al hassan) which focus on the spirit of compassion and mutual assistance to those in need, provide even more resilience and viable solutions for a more socially and economically just society.

The waqf framework is an important Islamic social financial instrument that can be used to provide an effective response to the imminent economic challenge in the post-pandemic period, which will be the subject of this paper. Waqf is the Islamic endowment that has been recognised historically as a viable instrument to facilitate religious and socioeconomic growth in Muslim society, especially in the area of education, infrastructure development, and healthcare. It also plays a significant role in alleviating poverty (Habib, 2004). Waqf is acknowledged as an important organ in the Islamic social finance sector, and is part of the voluntary system, alongside other forms of Islamic philanthropy (zakah, sadaqah, and Islamic microfinance) (IRTI Social Finance Report, 2017). The important role of waqf in meeting various socio-economic needs lies within its immense potential, as evidenced by the valuation of waqf assets around the world, estimated to range from RM418 billion to RM4.18 trillion (World Bank Group, INCEIF \& ISRA, 2019).

The primary objective of waqf transcends the usual spiritually driven charity and is based on the principle of continuous charity which is sustainable, as shown in the prosperous time of Islamic civilisation in the past (Sadeq, 2002). Globally, waqf has experienced a significant revival as tremendous effort and attention has been directed to realising its enormous potential as a tool for mobilising capital to boost social development (Cajee, 2007). Hence, the socio-economic deprivation that is currently taking place as a result of the Covid-19 outbreak should increase the need to research the potential opportunities provided by the waqf institutions (Nazari, 2020). Therefore, this paper seeks to analyse the latest trends in waqf ventures and the revenue generation activities of waqf institutions in Malaysia, and further draws on the ability of the waqf institutions to support society in the post-Covid-19 economic crisis.

\section{LITERATURE REVIEW}

\section{Concept of Waqf and Waqf Management}

Waqf (or awqaf for plural) is an Arabic term that applies to many closely related connotations, such as 'Islamic charitable giving', 'Islamic or pious endowment', 'perpetual endowment', 'charitable trust' and others, with the key goals of promoting social growth and the general public good (Kahf, 2007). The literal translation of the term 'waqf' is 'to keep', therefore, possesses unique and inherent qualities of perpetuity, irrevocability, and inalienability, which make the 
waqf distinct from other Islamic charitable entities (such as zakah and sadaqah) (Sadeq, 2002). Although the word waqf is not expressly stated in the Islamic tradition (i.e. Al-Quran and Al-Hadith), the meaning and practice of waqf can be traced back to the life of Prophet Muhammad (pbuh) (Dallal, 2004). The prominent hadith to which reference has been made regarding the basic principles of waqf is the hadith of Sayyidina Umar Al-Khattab (r.a), who had acquired the land of Khaybar (in Madinah, Saudi Arabia) and sought the Prophet (pbuh), who instructed him to make the property inalienable and distribute the usufruct as a charity. From the hadith, the core principles of waqf were derived, including the inalienability, irrevocability, perpetuity, and the use of usufruct. The purpose of waqf transcends that of normal charity as the key purpose of waqf is to attain closeness to Allah S.W.T by letting go of beloved property for continuous charity, and through pious deeds that endure long after the endower (founder) dies.

Establishing waqf involves the fulfilment of conditions, including the endower (founder/waqif), property (mauquf), beneficiaries (mauquf 'alaih), and waqf deeds (sighah/waqfiyah) (JAWHAR, 2018). Waqf acts in accordance with the general principles of Islamic law (fiqh), as compared to the zakah, in which the fiqh of waqf differs (among the four main fiqh mazhab). Thus, the waqf functions differently depending on locality and the needs of the time. As a summary, waqf may be divided into two types: (1) waqf ahli, which refers to the waqf property held for the family of its owner until it is differentiated from its descendants; (2) waqf khayri, which refers to the dedication of waqf property for charitable purposes. In the Malaysian context, waqf ahli is assumed to be no longer involved in public practice (although it can still be conducted on an individual basis, and is still operated by some waqf institutions for old waqf ahli), as the regulatory framework of waqf currently encourages the establishment of waqf khayri, which brings greater benefit to society at large. Furthermore, waqf khayri can be further divided into two purposes: (1) religious purposes (e.g. mosques, graveyards, huffaz school); (2) philanthropic or social purposes (enhancing general socio-economic welfare, including assistance to the poor and needy, education, health care, infrastructure). The current development of the waqf sphere is witnessing the revitalisation of waqf to realign its potential to bring about socio-economic growth in society, following a degenerate period of mismanagement and the misconception of waqf as being solely for religious purposes, with many waqf assets remaining undeveloped (Abdullah, 2020).

As far as waqf management is concerned, the role of the trustee (mutawalli or nazir), as the entrusted party to manage the waqf assets and waqf funds has developed since the early waqf period (Cizacka, 2000). Traditionally, the trusteeship of waqf assets has been granted to a religious person recognised in society and even the founder may also be a trustee of his own waqf, in the case that he or she knows how to manage waqf assets. Furthermore, after a considerable period of time, individual trusteeship becomes problematic, due to corruption and mismanagement (distrust of the descendants named following the death of the ancestor trustee) in the majority of the Muslim world. Following this, the trusteeship of waqf was taken over by the government, and the administration of waqf was handed over to the 'institutional trustee'. Although some studies documented criticism towards government intervention which has resulted in inefficient waqf management, the role of government in managing waqf is still prevalent in many jurisdictions through the establishment of departments or ministries dedicated to overseeing waqf management and development, especially in Muslim countries or Muslim-majority countries (IRTI Social Finance Report, 2014).

In the Malaysian context, waqf, being an Islamic matter, falls under the state authority according to the federal constitution. Each state (of 14 states in Malaysia) has its own jurisprudence through an enactment that governs the waqf administration. Waqf administration at the state level is managed by the council known as the State Islamic Religious Council (SIRC). Hence, differing waqf management across SIRCs stems from the different fatwa and governance employed. Most states have placed waqf management in the department or specific department of SIRC and waqf management, therefore, has a framework of public service. Nonetheless, several states have established their own corporate body to enable corporate-style management to be implemented in managing waqf assets and funds. Hence, the Malaysian context through the role of SIRC as the 'sole trustee' for waqf, as prescribed by the state law, represents an extreme case of government involvement in waqf management when compared to other Muslim-majority countries.

\section{METHODOLOGY}

This study utilised secondary data collection and content analysis to examine the current trends of waqf management, to conceptually provide future directions that can be taken by waqf institutions especially in Malaysia - a Muslim-majority country- to help society in the upcoming years of economic challenges. The data were collected through the SIRCs' website, bulletins, news, newsletters, and scholarly articles. The data were analysed to find patterns and trends through coding and themed analysis.

\section{FINDINGS AND DISCUSSION}

\section{Current trends of waqf management State Islamic Religious Council (SIRC)}

As the SIRC in each state plays the role of being the sole trustee of all waqf in their respective region, all waqf assets are registered and managed by the SIRC or entity appointed by the SIRC. Table 4.1 provides the details of the management style adopted by each SIRC in Malaysia, and their current waqf developments or projects. As for waqf management, the vast majority of SIRCs (10 SIRCs) placed the management of waqf under a special department or unit under the SIRC which is known as either the specific 'waqf department or waqf unit' or a combined department, such as 'department of waqf and general resources'. On the other hand, the remaining four SIRCs (i.e. Pulau Pinang, Kedah, Selangor, and Wilayah Persekutuan) have established their own corporate body, either as an agency such as Perbadanan Wakaf 
Selangor, or a subsidiary company as in Pulau Pinang, Kedah, and Wilayah Persekutuan. As previously mentioned, the reason for the establishment of a separate corporate body to specifically manage the waqf assets is to allow the corporate management style by bringing the professionals to the entity. As for the Sabah state, although waqf is currently managed by a waqf department under the SIRC, a separate entity known as Lembaga Pengurusan Wakaf Negeri Sabah was established in 2019, but waqf management is yet to be passed over to this particular entity by the SIRC. Nonetheless, overall waqf development in Sabah is relatively underdeveloped compared to that of other states. In 2019, changes were witnessed in the waqf management of state Negeri Sembilan, whereby the waqf management, previously managed by a separate corporate entity (SIRC subsidiary company) known as Perbadanan Wakaf Negeri Sembilan Sdn. Bhd. was restructured and merged to be a waqf department under the new establishment of Perbadanan Baitulmal Negeri Sembilan (an agency under SIRC Negeri Sembilan).

Table 1: Waqf management and projects by SIRCs in Malaysia

\begin{tabular}{|c|c|c|c|c|c|c|c|}
\hline \multirow{2}{*}{ State } & \multirow{2}{*}{$\begin{array}{c}\text { Waqf } \\
\text { Management } \\
\end{array}$} & \multicolumn{5}{|c|}{ Waqf Property (General \& Specific Waqf) } & \multirow{2}{*}{$\begin{array}{l}\text { Cash } \\
\text { Waqf }\end{array}$} \\
\hline & & Religious & Social & Commercial & Educational & Healthcare & \\
\hline Perlis & $\begin{array}{l}\text { SIRC- Waqf } \\
\text { Department/Unit }\end{array}$ & $\begin{array}{l}\text { - Mosque } \\
\text {-Graveyard } \\
\text {-Mortuary } \\
\text { management } \\
\text { center }\end{array}$ & & $\begin{array}{l}\text { Waqf Complex - } \\
\text { multipurpose hall }\end{array}$ & $\begin{array}{l}\text { Educational } \\
\text { Center }\end{array}$ & & Yes \\
\hline $\begin{array}{l}\text { Pulau } \\
\text { Pinang }\end{array}$ & $\begin{array}{l}\text { Corporate - } \\
\text { Wakaf Pulau } \\
\text { Pinang Sdn. Bhd. }\end{array}$ & $\begin{array}{l}\text { - Mosque } \\
\text { - Graveyard }\end{array}$ & & $\begin{array}{l}\text { - Housing } \\
\text { - Business } \\
\text { premises } \\
\text { - Office premises } \\
\text { - Bazaar } \\
\text { - Hotel } \\
\end{array}$ & $\begin{array}{l}\text { - School for } \\
\text { Huffaz } \\
\text { (maahad) }\end{array}$ & & $\begin{array}{l}\text { Yes* } \\
*\end{array}$ \\
\hline Kedah & $\begin{array}{l}\text { Corporate - } \\
\text { Pengurusan } \\
\text { Izzah Sdn Bhd }\end{array}$ & $\begin{array}{l}\text { - Mosque } \\
\text { - Graveyard }\end{array}$ & & $\begin{array}{l}\text { - Housing } \\
\text { - Business } \\
\text { premises } \\
\text { - Office premises }\end{array}$ & & & Yes \\
\hline
\end{tabular}

\begin{tabular}{|c|c|c|c|c|c|c|c|}
\hline Perak & $\begin{array}{l}\text { SIRC- Waqf } \\
\text { Department/Unit }\end{array}$ & $\begin{array}{l}\text { - Mosque } \\
\text { - Graveyard }\end{array}$ & & $\begin{array}{l}\text { - Business } \\
\text { premises }\end{array}$ & $\begin{array}{l}\text { - School for } \\
\text { Huffaz } \\
\text { (maahad) } \\
\text { - Quranic } \\
\text { Education } \\
\text { Center } \\
\text { - } \\
\text { Training/Intens } \\
\text { ive class for } \\
\text { the poor } \\
\text { - USAS } \\
\text { student } \\
\text { dormitory } \\
\text { building }\end{array}$ & $\begin{array}{l}\text { Haemodial } \\
\text { ysis Center }\end{array}$ & $\begin{array}{l}\text { Yes* } \\
*\end{array}$ \\
\hline Pahang & $\begin{array}{l}\text { SIRC - Waqf } \\
\text { Department/Unit }\end{array}$ & $\begin{array}{l}\text { - Mosque } \\
\text { - Graveyard }\end{array}$ & $\begin{array}{l}\bullet \\
\text { Asnaf } \\
\text { Compl } \\
\text { ex - } \\
\text { shelter } \\
\text { for the } \\
\text { poor, } \\
\text { needy, } \\
\text { and } \\
\text { mualaf } \\
\text {, }\end{array}$ & $\begin{array}{l}\text { Agriculture/aquacu } \\
\text { lture project }\end{array}$ & $\begin{array}{l}\text { - Student } \\
\text { dormitory in } \\
\text { Mesir } \\
\text { - Agriculture } \\
\text { training }\end{array}$ & & Yes \\
\hline $\begin{array}{l}\text { Kelant } \\
\text { an }\end{array}$ & $\begin{array}{l}\text { SIRC - Waqf } \\
\text { Department/Unit }\end{array}$ & $\begin{array}{l}\text { - Mosque } \\
\text { - Graveyard }\end{array}$ & $\begin{array}{l}\text { Mualaf } \\
\text { Centre }\end{array}$ & $\begin{array}{l}\text { - Housing } \\
\text { - Business } \\
\text { premises } \\
\text { - Bazaar }\end{array}$ & $\begin{array}{l}\text { - School for } \\
\text { Huffaz } \\
\text { (maahad) }\end{array}$ & $\begin{array}{l}\text { Medical } \\
\text { equipment } \\
\text { for Health } \\
\text { Center }\end{array}$ & Yes* \\
\hline
\end{tabular}




\begin{tabular}{|c|c|c|c|c|c|c|c|}
\hline & & & & & $\begin{array}{l}\text { - Islamic } \\
\text { school }\end{array}$ & & \\
\hline $\begin{array}{l}\text { Tereng } \\
\text { ganu }\end{array}$ & $\begin{array}{l}\text { SIRC - Waqf } \\
\text { Department/Unit }\end{array}$ & $\begin{array}{l}\text { - Mosque } \\
\text { - Graveyard }\end{array}$ & & $\begin{array}{l}\text { - Business } \\
\text { premises }\end{array}$ & & & $\begin{array}{l}\text { Yes* } \\
*\end{array}$ \\
\hline $\begin{array}{l}\text { Melak } \\
\quad \mathrm{a}\end{array}$ & $\begin{array}{l}\text { SIRC - Waqf } \\
\text { Department/Unit }\end{array}$ & $\begin{array}{l}\text { - Mosque } \\
\text { - Graveyard }\end{array}$ & & $\begin{array}{l}\text { - Business } \\
\text { premises } \\
\text { - Bazaar }\end{array}$ & & & Yes \\
\hline $\begin{array}{l}\text { Selang } \\
\text { or }\end{array}$ & $\begin{array}{l}\text { Corporate - } \\
\text { Perbadanan } \\
\text { Wakaf Selangor }\end{array}$ & $\begin{array}{l}\text { - Mosque } \\
\text { - Graveyard }\end{array}$ & & $\begin{array}{l}\text { - Housing } \\
\text { - Business } \\
\text { premises } \\
\text { - Office premises } \\
\text { - Bazaar }\end{array}$ & $\begin{array}{l}\text { - School for } \\
\text { Huffaz } \\
\text { (maahad) } \\
\text { - Islamic } \\
\text { school }\end{array}$ & & Yes \\
\hline $\begin{array}{l}\text { Negeri } \\
\text { Sembil } \\
\text { an }\end{array}$ & $\begin{array}{l}\text { SIRC - Waqf } \\
\text { Department/Unit }\end{array}$ & $\begin{array}{l}\text { - Mosque } \\
\text { - Graveyard }\end{array}$ & & $\begin{array}{l}\text { - Bazaar/ wakaf } \\
\text { mart }\end{array}$ & & $\begin{array}{l}\text { Clinic and } \\
\text { Haemodial } \\
\text { ysis Center }\end{array}$ & Yes \\
\hline Johor & $\begin{array}{l}\text { SIRC - Waqf } \\
\text { Department/Unit }\end{array}$ & $\begin{array}{l}\text { - Mosque } \\
\text { - Graveyard }\end{array}$ & $\begin{array}{l}\text { Center } \\
\text { for } \\
\text { women } \\
\text { shelter }\end{array}$ & $\begin{array}{l}\text { - Palm oil } \\
\text { plantation } \\
\text { - Business } \\
\text { premises } \\
\text { - } \\
\text { Telecommunicatio } \\
\text { n tower }\end{array}$ & & & Yes \\
\hline $\begin{array}{l}\text { Wilaya } \\
\text { h } \\
\text { Persek } \\
\text { utuan }\end{array}$ & $\begin{array}{l}\text { Corporate - } \\
\text { Pusat Wakaf } \\
\text { MAIWP Sdn. } \\
\text { Bhd. }\end{array}$ & $\begin{array}{l}\text { - Mosque } \\
\text { - Graveyard }\end{array}$ & & $\begin{array}{l}\text { - Business/ office } \\
\text { premises (Menara } \\
\text { Imarah Wakaf) }\end{array}$ & & & Yes \\
\hline Sabah & $\begin{array}{l}\text { SIRC }- \text { Waqf } \\
\text { Department/Unit } \\
*\end{array}$ & $\begin{array}{l}\text { - Mosque } \\
\text { - Graveyard }\end{array}$ & & & & & Yes \\
\hline $\begin{array}{c}\text { Sarawa } \\
\mathrm{k} * * *\end{array}$ & $\begin{array}{l}\text { SIRC - Waqf } \\
\text { Department/Unit }\end{array}$ & NA & NA & NA & NA & NA & Yes \\
\hline
\end{tabular}

* Majlis Ugama Islam Sabah (MUIS) has established an entity to manage the waqf in Sabah state known as Lembaga Pengurusan Wakaf Negeri Sabah. However, to date, the management of waqf is yet to be passed over to that entity by MUIS.

**The collection of cash waqf will be changed to the immovable assets.

*** Data on the waqf project and developments in Sarawak state could not be found on their SIRC'a website, bulletins, news, or related disclosures. The only information available was on the collection of cash waqf.

\section{Current trends of waqf projects and developments by the State Islamic Religious Council (SIRCs)}

Regarding the current waqf projects and developments managed by the SIRCs, Table 4.1 above also shows the two categories of waqf: the development of waqf property and cash waqf. Both categories of waqf (property and cash waqf) consist of specific waqf (known as waqf khas - waqf established for a specific purpose, usually a religious purpose) and general waqf (known as waqf am - waqf established for general socio-economic purposes). Five main themes emerged for current waqf projects and developments focused on property: (1) religious, (2) social, (3) commercial, (4) educational, and (5) healthcare. The religious focus has been consistently developed by all SIRCs, which is basically related to the establishment of places of worship including mosques and small mosques, and also graveyards. These types of waqf development are arguably being the most important and the most symbolic of waqf, being synonymous with the waqf tradition from the early days and among the majority of Muslims across the world (Abdullah, 2020). Evidently, the vast majority of the waqf land endowed by donors (waqif) to the SIRCs was land intended for religious purposes. The next category of waqf projects and property development is the social focus. The social focus basically is referring to the projects or properties established to improve the lives of poor and needy people, and vulnerable groups of people. Interestingly, only a few SIRCs have developed and managed waqf property for the social focus namely the Asnaf Complex in Pahang, Mualaf Center in Kelantan, and the Center for Women Shelter in Johor. However, this trend can be explained by the social focus (targeting poor and needy people, mualaf, etc.) being the main concern of the zakah fund. 
Therefore, fewer waqf projects are focused on the social purpose to avoid overlapping with the projects and property development designated for social purposes, catered through the zakah fund.

Next, the commercial focus category is referring to waqf projects and development established with the purpose of generating income, which is subsequently redistributed to the intended beneficiaries and reinvested in order to generate more economic income. The findings showed that the majority commercialisation focus of the SIRCs was the development of investment properties to gain rental income from housing, business premises, office premises, bazaars, and similar projects (Mohd Fairuz et al., 2018; Fathiyyah et al., 2019). This form of development is considered to represent a low risk, presumed to be suitable for the sustainability of waqf. Nonetheless, a few interesting observations can be made for some SIRCs (for example, Pulau Pinang and Selangor), which have shown relatively more progress towards commercialisation with the indication that a significant number of waqf properties have been developed for commercial purposes, as compared to other SIRCs. This may be explained by the fact that the position of the waqf property, due to the positive demand for commercial, typically must be situated in an urban area for a better commercialisation opportunity. Other than that, it is possible that the corporate structure of waqf management employed by these states may be a contributing factor to the emphasis on commercialisation. It is also worth noting that a few SIRCs have begun the initiative of a distinct form of waqf projects for commercial purposes, which is tailored to local socio-economic needs, such as Pahang (agriculture and aquaculture project) and Johor (a palm oil plantation).

In respect of the last two categorisations of current waqf projects and development, the educational and healthcare focus has also been recognised as a common waqf tradition and a symbol for society development. Examples of waqf projects and property development for the educational focus, which are specifically managed by SIRCs, include the school for Huffaz, Islamic school, educational center and training, and dormitories for college and university students. On the contrary, in a few states, such as Perak and Negeri Sembilan, the waqf for the healthcare sector, currently being operated by SIRCs takes the form of haemodialysis centres. However, several other waqf projects for the healthcare sector are being developed by the SIRCs in partnership with Islamic banks and even private companies, which will be addressed in the next subsection.

Cash waqf, on the other hand, is consistently practised and promoted by all SIRCs through several names, such as the cash waqf scheme, cash waqf fund, and waqf share. Some SIRCs clearly mentioned that the collection of cash waqf is for the purpose of the acquisition of immovable assets to ensure the perpetuity of waqf (e.g. Pulau Pinang, Perak, Kelantan, and Terengganu). Other states such as Selangor recognised the cash waqf as waqf itself, hence not being necessary to convert this to the immovable assets. The different practices are due to the different fatwa applied to each state regarding cash waqf, which is not a new debate (Cizacka, 2000).

\section{Other waqf projects and developments}

This subsection briefly discussed other waqf projects and developments of SIRCs, with collaborations of federal agencies (Yayasan Wakaf Malaysia), Islamic banks (known as myWakaf Campaign), and private entities such as the Johor Corporation, KPJ Healthcare Berhad, and Uda Waqf Sdn Bhd.

\section{Yayasan Wakaf Malaysia}

Two federal level institutions were established in the Department of Awqaf, Zakah and Hajj or Jabatan Wakaf, Zakat dan Haji (JAWHAR) in 2004 and its foundation, known as the Malaysia Waqf Foundation or Yayasan Wakaf Malaysia (YWM) in 2008 mainly to play roles in the coordination and fostering of waqf development as a stimulus fund covering an RM250 million national budget had been allocated in the Ninth Malaysia Plan (2006 - 2010), which funded several notable projects such as hotels (located in Perak, Melaka, and Terengganu), educational and healthcare facilities complex, and bazaar (Ahmad, Muhammad, \& Kamaruzaman, 2012). Other than that, YWM also implemented the cash waqf collection for various philanthropic and social purposes and owned a few waqf investment properties across Melaka, Kedah, and Selangor to earn rental income.

\section{myWakaf Campaign}

The myWakaf campaign is among the recent initiatives to boost the waqf role as an important instrument for financial inclusion and economic growth. This programme is jointly managed and organised by the SIRCs and Islamic banks (the current participating banks are the Affin Islamic Bank Berhad, Bank Islam Malaysia Berhad, Bank Muamalat Malaysia Berhad, Bank Rakyat, Maybank Islamic Berhad, and RHB Islamic Malaysia Berhad) to create a pool of waqf funds which can be channelled into four sectors: education, health, investment, and economic empowerment. Table 4.2 below provides the details of the current projects under myWakaf campaigns according to the prescribed sectors. 
Table 2: Projects under myWakaf Campaign

\begin{tabular}{|c|c|c|c|}
\hline Education & Health & Investment & $\begin{array}{c}\text { Economic } \\
\text { empowerment }\end{array}$ \\
\hline $\begin{array}{c}\text { Dana Wakaf Al-Bait } \\
\text { (Sarawak) }\end{array}$ & $\begin{array}{l}\text { HTF Hemodialysis Center } \\
\text { (Perlis) }\end{array}$ & - & Boat waqf (Perak) \\
\hline Inap Waqf (Kedah) & Dental Clinic (Selangor) & - & \\
\hline $\begin{array}{l}\text { Sek. Men. Islam } \\
\text { (N.Sembilan) }\end{array}$ & $\begin{array}{c}\text { MAIDAM Hemodialysis Center } \\
\text { (Terengganu) }\end{array}$ & - & \\
\hline $\begin{array}{l}\text { Mualaf Center Renovation } \\
\text { (Kelantan) }\end{array}$ & & & \\
\hline
\end{tabular}

\section{Waqf as Corporate Social Responsibility by Private Entities}

A few private entities actively engage in the development of waqf funds and projects, including Johor Corporation, KPJ Healthcare Berhad, and Uda Waqf Sdn Bhd. Johor Corporation (JCorp), through its subsidiary known as Waqaf AnNur Corporation Berhad (WANCorp) to manage various waqf assets (mosques and Waqaf An-Nur Clinics ) and waqf shares of JCorp. Additionally, UDA Holdings Berhad established a subsidiary known as Uda Waqf Sdn. Bhd. with the purpose of collaborating with SIRCs and other interested parties to develop the waqf property through joint ventures and other shariah-compliant arrangements. For example, the collaboration between SIRC Pulau Pinang and Uda Waqf Sdn. Bhd. successfully developed the Taman Waqf Setee Aishah in Penang.

\section{Possible Prospects for Waqf Institutions for Economic Revival in the Post-Covid-19 Era}

On the basis of the findings regarding the current trends of waqf projects, waqf in Malaysia can be viewed in optimistic terms. Nonetheless, there is still room for improvement, particularly in relation to the roles and prospects for waqf institutions (SIRCs) in participating in the economic challenge and recovery required due to the recent Covid-19 pandemic. As the Covid-19 crisis plunged economies into the struggle with unemployment and downturn, waqf can be a long-term solution through the efficient and effective utilisation of existing idle waqf assets. Due to the limited funds for waqf development, the current cash waqf scheme can be further strengthened to provide a greater pool of funds for sustaining the basic needs of poor and needy people with initiatives such as food banks, housing, and education support. The current myWakaf model appears viable as a vehicle and needs to invite more participating organisations such as private companies and public companies, to improve the collection of the cash waqf and finance promising sectors, as envisaged in the myWakaf campaign. The myWakaf model should empower the economy through a mudharabah arrangement to support entrepreneurship (halal business) and social innovation. Furthermore, waqf should also be actively promoted and highlighted as a mean of corporate social responsibility (CSR) as practised by a few private entities, as mentioned in the previous section.

In addition, it is also prudent to set up a specific waqf fund for emergency and disaster preparation, created as a lesson learned from the recent pandemic crisis to meet the urgent needs of vulnerable groups that are highly exposed to and impacted by economic instability. This fund should be invested in viable form of investments to expand the fund which should be distributed to the entitled group of people during crises. Nonetheless, while the zakah fund can be utilised for short-term solutions for society, waqf in its essence should be directed towards more sustainable and viable revenue generation investment for long-term socio-economic solutions, creating synergies' with the zakah fund and other Islamic social finance tools (such as sadaqah and qard al hassan). Although several notable waqf projects intended for investment to gain economic income can be seen in current waqf trends, more innovation is certainly required to strengthen this initiative. Therefore, waqf inevitably requires not only a viable pool of economic resources but also knowledge and skill resources contributed by Muslim professionals to the waqf institution in order to enhance the waqf initiatives. Simultaneously, the waqf institutions must also be ready to 'unlatch the door' to allow more collaborative efforts for the purpose of waqf development, which brings benefit to the entire society.

\section{CONCLUSION}

Waqf institutions need to seek many innovations to be able to manoeuvre within their constraints to provide various socio-economic opportunities to benefit society, including projects that can cater to the basic needs of vulnerable groups (poor and needy people) and job creation. The existence of waqf assets (including hotels, agricultural land, and bazaars) can also be further realigned to provide a means to achieve immediate and long-term sources of income especially for those who are socially disadvantaged. Besides, cash waqf can be a powerful medium to pool sources of waqf funds which can be channelled to various charitable projects, shariah-compliant businesses, and investments. However, challenges are anticipated as the struggle to attain sufficient waqf funds to progress waqf development could be intensified in the postpandemic era. Nevertheless, changes towards more efficient, effective, and innovative management were ultimately 
necessary to catalyse the success of waqf projects in combating the socio-economic struggles faced by society. Moreover, changes in the social and economic landscape due to the recent pandemic has, inevitably, created more opportunities to innovate and also induced changes in institutions and society.

This paper mainly offers a theoretical study motivated by the current economic conditions caused by the recent global health crisis which requires a sustainable solution through Islamic social finance instruments. In doing so, the paper has provided some significant practical insights by drawing the possible prospects for the waqf institutions to embark, and also acts as a catalyst for change in societal values by applying the central role of kindness in assisting each other, and the particularly emphatic act of the rich helping poor people through waqf donations. These values should be imprinted in society as lessons learned from the global health and economic crisis which cannot be simply solved while maintaining the existing capitalistic and individualistic mind-set. However, the findings presented in this paper are subject to several limitations that require careful reader interpretation. Firstly, there is a limitation in regards to the use of secondary data (websites, bulletins, news, reports) which may contribute to the lack of knowledge on the current waqf projects and lack of growth from weak SIRC disclosure practices. Secondly, due to the unavailability of such factual information or data, the current waqf projects and the developments presented in this paper have been generally mentioned without taking account of their actual value (RM). Further studies should therefore be undertaken to provide a full picture of the current waqf projects and their growth including the actual revenues produced and distributed to beneficiaries.

\section{REFERENCES}

Abdullah, M. (2020). Waqf, Social Responsibility and Real Economy, Chapter 2 in Challenges and Impacts of Religious Endowments on Global Economics and Finance, IGI Global.

Ahmad, A., Muhammad, S. \& Kamaruzaman, M.A.S. (2012). Education Development Through Waqf, paper was presented at 3rd International Conference on Islam and Higher Education (3rd ICIHE), 1st - 2nd October 2012, Pahang State Foundation Complex, Kuantan, Malaysia, Organized by Pahang State Foundation.

Cajee, Z. (2007). Revitalising the institution of awqaf in developing the community. Singapore International Waqf Conference 2007.

Cizacka, M. (2000). A history of philanthropic foundations: The Islamic world from the seventh century to the present. Istanbul: Bogazici University Press.

Dallal, A. (2004), The Islamic Institution of Waqf: A Historical Overview, Chapter 1 in book Islam and Social Policy (Stephen P. Heyneman) 1st edition, Vanderbilt University Press, Nashville.

Fathiyyah, A.B., Ku Nor Izah, K.I., Chek Derashid, Norfaiezah, S., Muhammad Syahir, A.B., \& Suhaimi, I. (2019). Perakaunan Hasil Wakaf bagi Majlis Agama Islam Negeri di Malaysia, IPN Journal of Research and Practice in Public Sector Accounting and Management, 9 (1): 85-101.

Habib, Ahmed (2004), Role of Zakat and Awqaf in Poverty Alleviation, Occasional Paper No.8, Islamic Development Bank, Jeddah, Saudi Arabia.

IRTI Social Finance Report (2014) Islamic Research and Training Institute (IRTI).

IRTI Social Finance Report (2017) Islamic Research and Training Institute (IRTI).

JAWHAR (2018) Manual Panduan Pengurusan Wakaf Institut Pendidikan, Jabatan Wakaf Zakat dan Haji (JAWHAR).

Kahf, M. (2007) The role of waqf in improving the ummah welfare. Singapore International Waqf Conference 2007 on 6-7 March 2007. The Fullerton Hotel Singapore.

Kajian Pelan Induk Transformasi Harta Tanah Wakaf Negara by JAWHAR (2016).

Mohd Fairuz, M.S, Norida, B., Azlina, A., Azizah, M.H, Hairunnizam, W., \& Ainol Basirah, A.W. (2018). Amalan Pengiktirafan Hasil oleh Institusi Wakaf, Zakat dan Baitulmal di Malaysia, IPN Journal of Research and Practice in Public Sector Accounting and Management, 8 (1): 1-22.

Nazari Ismail, March 28, 2020, Consider Waqf as Global Financial Cure for Economic Revival Post Covid-19, Retrieved May 31, http://english.astroawani.com/malaysia-news/consider-waqf-global-financial-cure-economic-revival-post-covid-19-235682

Sadeq, A. M. (2002). Waqf, Perpetual Charity and Poverty Evaluation. International Journal of Social Economics, 29(1/2), 135-151.

The World Bank Group, INCEIF, \& ISRA (2019). Report on Maximizing Social Impact Through Waqf Solutions, May 2019.

\section{ACKNOWLEDGEMENT}

The authors would like to express their gratitude and appreciation to the Malaysian Ministry of Education for the funding of this research through the fundamental research grant scheme (FGRS): Grant no. 203. PPAMC.6711633. 


\section{AUTHORS' BIOGRAPHY}

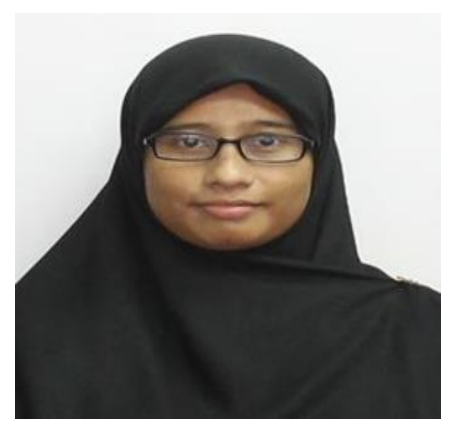

A.W. Ainol-Basirah is a lecturer at the Faculty of Economics and Management, Universiti Kebangsaan Malaysia. She is currently pursuing her PhD study at the Graduate School of Business, Universiti Sains Malaysia. Her current research is concerned with accountability in the waqf institution.

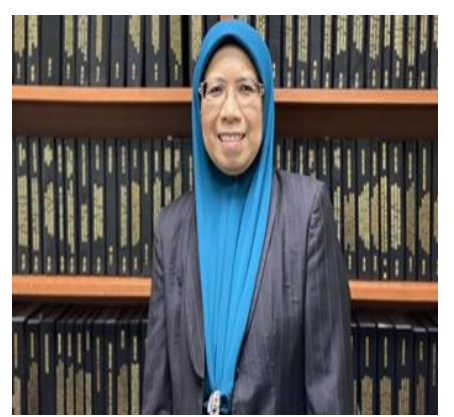

A.K. Siti-Nabiha is a Professor at the Graduate School of Business, Universiti Sains Malaysia. Her research interest is in the area of management accounting, specifically on issues related to accounting and organisational change, performance measurement and systems of accountability and sustainability control system in both public and private sectors. 